\title{
Problems Threatening the Tigris Trout (Salmo tigridis Turan, Kottelat \& Bektaş, 2011) Stock in Çatak Stream and Some Recommendations
}

\author{
Mustafa AKKUŞ1 Mustafa SARI² \\ ${ }^{1}$ Department of Aquaculture, Faculty of Fisheries, Van Yüzüncü Yıl University, Van Turkey \\ ${ }^{2}$ Faculty of Maritime, Bandırma Onyedi Eylül University, Balıkesir, Turkey
}

\begin{abstract}
Received: 02.12 .2017
Accepted: 22.12 .2017

Available online: 25.12 .2017

Published: 29.12.2017

Abstract: This study was carried out to reveal the problems threatening Salmo tigridis stock inhabited in Çatak Stream and to offer some solutions to overcome these problems. Çatak is the largest stream of the region and located at $81 \mathrm{~km}$ southern of the Van city center. Salmo tigridis, which is only distributed in Çatak and Bahçesaray streams, faces the danger of extinction. In this study, it was observed that sand-graveling activities at Çatak Stream muddied the stream and destroyed appropriate reproduction habitats. Another problem is that Çatak Stream's over-destruction of vegetation in the catchment basin increases flood risk and flood-related sudden flow increases. In addition, it was determined that studies carried out for river improvement and flood control disturbed the natural flow regime of the stream, leading to deterioration in the base and coastal structure. Another threat is the rainbow trout (Oncorhynchus mykiss) that escape from fish farms. Catching with prohibited methods and fishing gears is also a problem that threatens the future of native trout stock in the stream. With this study, the problems that threaten the tigris trout stock in Çatak Stream were identified and some proposals were presented.
\end{abstract}

Keywords: Tigris Trout, Salmo tigridis, invasive species, habitat destruction, Çatak stream, water quality

\section{Dicle Alabalığı (Salmo tigridis Turan, Kottelat \& Bektaş, 2011) Çatak Çayı Stokunu Tehdit Eden Sorunlar ve Bazı Çözüm Önerileri}

Özet: Bu çalışma Çatak Çayı'nda yaşayan dağ alabalığı Salmo tigridis stokunu tehdit eden sorunlar ve sorunların çözüm yollarını ortaya koymak amacıyla yapılmıştır. Çatak Çayı Van il merkezinin $81 \mathrm{~km}$ güneyinde bulunur ve bölgenin en büyük akarsularındandır. Yalnızca Çatak ve Bahçesaray Çaylarında dağılım gösteren Salmo tigridis bu çaylarda yok olma tehlikesi ile karşı karşıyadır. Yapılan bu çalışmada Çatak Çayı'nda kum-çakıl alma faaliyetlerinin akarsuyu bulandırdığını ve uygun üreme habitatlarını yok ettiği gözlemlenmiştir. Çatak Çayı'nın su toplama havzasındaki vejetasyonun aşırı tahrip edilmesinin sel riskini artırması ve sele bağlı ani debi artışları ile bulanıklık diğer bir problemdir. Diğer taraftan dere ıslahı ve sel kontrolü amacıyla yapılan çalışmaların çayın doğal akış rejimini bozarak taban ve kıyı yapısında bozulmalara yol açtığı belirlenmiştir. Diğer bir sorun ise balık çiftliklerinden kaçan gökkuşağı alabalıklarıdır (Oncorhynchus mykiss). Çatak Çayı'nda, kullanımı yasak yöntemler ve av araçları ile yapılan avcılık da alabalık stokunun geleceğini tehdit eden sorunlardandır. Yapılan bu çalışma ile Çatak Çayı Dicle alabalığı stokunu tehdit eden sorunlar belirlenerek bazı çözüm önerileri sunulmuştur.

Anahtar kelimeler: Dicle alabalı̆̆ı, Salmo tigridis, istilacı tür, habitat tahribi, Çatak çayı, su kalitesi

\section{Introduction}

Increasing human-oriented impacts on streams result in the deterioration of the water quality and physical habitats of rivers. It was reported in several studies that these deteriorations caused negative effects on fish stock in rivers (Whitney 1994, Berkün et al. 2008, Bülbül 2009, Kang et al. 2014). In addition to the deterioration of the physical habitat and the water quality, the pressure of fishing on species with high economic value causes these species to decrease rapidly in Turkish inland waters. Brown trout prefer clean, fast flowing, cold mountain waters at high altitudes that range between 100-2300 m, with abundant oxygen and summer temperatures not exceeding $20^{\circ} \mathrm{C}$ (Aras 1974, Kurd 1976, Geldiay and Balık 2009). Trout is the economically most important indigenous fish species in Turkish streams. This species is extremely popular in Turkey and common in local fishing due to its taste, its use for medical purposes, and also its being prominent in sportive fishing. Because of these attractive properties of the trout mentioned above, illegal fishing methods such as fishing with dynamite, grenade, carbide, electrical shock, and light are popular in Turkey
(Korkmaz, 2005). Trout prefers clean and fast flowing waters which have abundant oxygen. Rehabilitation of rivers, construction of reservoirs, irrigation activities, drinking water discharges, and other activities have a negative effect on trout habitats. Furthermore, illegal and excessive fishing pressure on Salmonids can result in the decrease or extinction of the trout stocks (Alp and Kara 2004, Kara et al. 2007, Yeğen 2008).

It was reported that Tigris trout (Salmo tigridis Turan et al. 2011) is distributed in Çatak and Müküs streams which are tributaries of the upper Tigris River in Turkey (Turan et al. 2011, Kaya et al. 2016). Çetinkaya (1996) conducted the sole study on the biological properties of Çatak Stream Tigris trout population. Determination of the elements that threaten the Çatak Stream Tigris trout stock, which is one of the most important species of biodiversity in the region, is important for the sustainability of the stocks. In the present study, observations and investigations conducted in the Çatak Stream between 2013 and 2014 were examined and solutions to the problems that endanger the Tigris trout stock were presented. 


\section{Materials and Methods}

The Çatak Stream's source is in Sicaksu village $\left(37^{\circ} 50^{\prime}\right.$ $41^{\prime \prime} N 43^{\circ} 32^{\prime} 42^{\prime \prime} E$ ) with 2338 meter altitude (Fig. 1). Several creeks on the Çavuşşahap Mountains surround the Çatak Stream. The stream merges with the Bahçesaray Stream near Narsuyu village, and at this location it is called as Botan River. The Çatak Stream is $145 \mathrm{~km}$ long and passes through steep valleys with a height of 1000 meters (Saraçoğlu 1990). This study is conducted in the Çatak Stream between years 2013 and 2014. Sampling was done at 11 points (Table 1 ). The fish samples were collected monthly by using a 12-volt DC and 7-14 amperes battery-powered electroshock device with $650 \mathrm{~W}$ output power, fish ladle with spreading mesh and eye opening of 2-4 mm. Rapid Habitat Assessment Method (Barbour 1999), which evaluates river habitat by taking fish into consideration, was used in determining the physical habitat structure. The Rapid Habitat Assessment Method is a very useful method to examine river habitats.

Table 1: Sampling points in Çatak Stream

\begin{tabular}{lll}
\hline $\begin{array}{l}\text { Sampling } \\
\text { Points }\end{array}$ & Coordinates & \\
\hline 1 & $37^{\circ} 53^{\prime} 30.60^{\prime \prime} \mathrm{N}$ & $43^{\circ} 37^{\prime} 14.89^{\prime \prime} \mathrm{E}$ \\
2 & $37^{\circ} 52^{\prime} 07.50^{\prime \prime} \mathrm{N}$ & $43^{\circ} 35^{\prime} 11.97^{\prime \prime} \mathrm{E}$ \\
3 & $37^{\circ} 51^{\prime} 48.38^{\prime \prime} \mathrm{N}$ & $43^{\circ} 25^{\prime} 43.62^{\prime \prime} \mathrm{E}$ \\
4 & $38^{\circ} 0^{\prime} 54.33^{\prime \prime} \mathrm{N}$ & $43^{\circ} 24^{\prime} 14.51^{\prime \prime} \mathrm{E}$ \\
5 & $38^{\circ} 4^{\prime} 14.18^{\prime \prime} \mathrm{N}$ & $43^{\circ} 24^{\prime} 02.33^{\prime \prime} \mathrm{E}$ \\
6 & $38^{\circ} 6^{\prime} 15.16^{\prime \prime} \mathrm{N}$ & $43^{\circ} 16^{\prime} 30.86^{\prime \prime} \mathrm{E}$ \\
7 & $38^{\circ} 66^{\prime} 25.35^{\prime \prime} \mathrm{N}$ & $43^{\circ} 16^{\prime} 38.00^{\prime \prime} \mathrm{E}$ \\
8 & $38^{\circ} 5^{\prime} 48.27^{\prime \prime} \mathrm{N}$ & $43^{\circ} 14^{\prime} 14.95^{\prime \prime} \mathrm{E}$ \\
9 & $38^{\circ} 4^{\prime} 37.69^{\prime \prime} \mathrm{N}$ & $43^{\circ} 19^{\prime} 09.74^{\prime \prime} \mathrm{E}$ \\
10 & $38^{\circ} 2^{\prime} 48.16^{\prime \prime} \mathrm{N}$ & $43^{\circ} 17^{\prime} 28.00^{\prime \prime} \mathrm{E}$ \\
\hline 11 & $38^{\circ} 2^{\prime} 09.11^{\prime \prime} \mathrm{N}$ & $43^{\circ} 11^{\prime} 12.02^{\prime \prime} \mathrm{E}$ \\
\hline
\end{tabular}

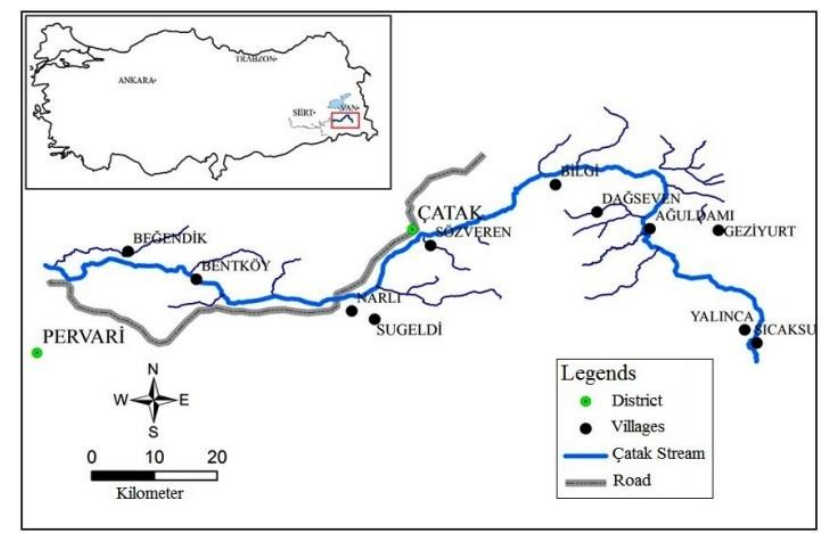

Figure 1: Çatak Stream

\section{Results}

\subsection{Excessive and illegal fishing}

It is known that there is extreme fishing pressure on economic species such as the brown trout that inhabits in the inland waters (Alp and Kara 2004, Altındağ and Ahiska 2006, Kurtoglu et al. 2009). Over-fishing pressure on Tigris trout is the leading problem that endangers the Çatak Stream. Tigris trout is caught illegally in every part of the stream due to its taste, its price, which is 4 or 5 times more expensive than that of the aquaculture trout, and the belief among people that it is therapeutic for certain diseases. Akkuş (2016) reported that because of the over-fishing pressure in the Çatak Stream, Tigris trout is completely withdrawn from certain parts of the stream. The fishing activities in the stream are conducted with netting, casting, gill net, electrical shock, anesthetic herbs, and different explosives. Also a fishing gear, which is called locally as 'Paraşüt' or 'tırıvırı', is used in the Çatak Stream. It is an illegal fishing gear wich is used with fishing line and made with snell pieces.

Particularly, tigris trout fishing is conducted with various explosives in areas close to the source and away from the residential areas. Fishing with explosive substances destroys feeding and breeding habitats for fish in addition to the death of all living organism in the stream. Following the use of explosives, using Paraşüt is the next fishing method that harms Tigris trout and other fish stocks in the Çatak Stream. It is known that the fishing tool known as Paraşüt damages fish stocks; however, its use in inland waters has been increasing every year (Ateşşahin et al. 2014, Dönel and Yılmaz 2016). When the Paraşüt is caught by the rocks on the bottom of the stream, it remains there for several years and keeps on fishing several living organisms (Fig. 2-3).

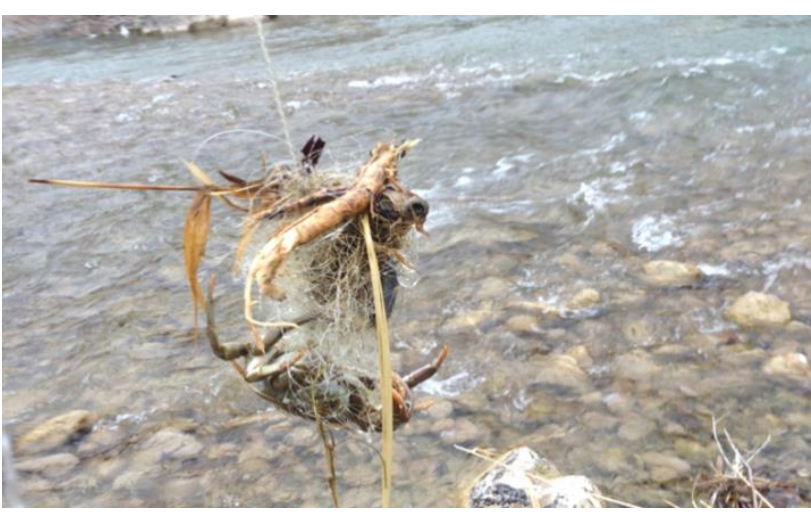

Figure 2: A crab caught in a broken Paraşüt in the stream

Paraşüt is a common fishing gear in the Çatak Stream and one of the major threats on Tigris trout. Another fishing method that endangers Tigris trout stock in the stream is conducted by releasing pulverized herbs with anesthetics or poisonous properties to the water. This method has been used since ancient times by fishermen and still utilized in several rivers in Turkey (Çelikkale et al. 1993, Atar and Ates 2009). In the Çatak Stream, Tigris trout fishing is conducted by pulverizing the mullein seeds or flowers (Verbascum sp.), especially in areas close to the source. In this method, all fish in the environment pass out and small fish as well as the big ones are caught. In the remaining areas, including the areas where Taşlıyazı and Elmalı streams join the Çatak Stream, fishing is prohibited all year round. In other areas, trout fishing is prohibited during between October 1 and March 31. However, these prohibitions are not enforced in the region; thus fishing continues in every region of the stream. 


\subsection{Destruction of the Physical Habitat}

Stream's physical habitats are suitable feeding and breeding areas for the fish. The destruction of these habitats that have been formed in millions of years destroys the habitats of all living organisms in the stream. In recent years, several activities such as stream improvements, the presence of sand quarries on streams, construction of highway bridges, HPPs, and reservoirs disrupted the physical habitat structure in the rivers. Stream improvement work deteriorated the riverbed structure and altered the flow regimes. These developments have a negative impact on fish stocks (Sar1 and Akkus 2015).

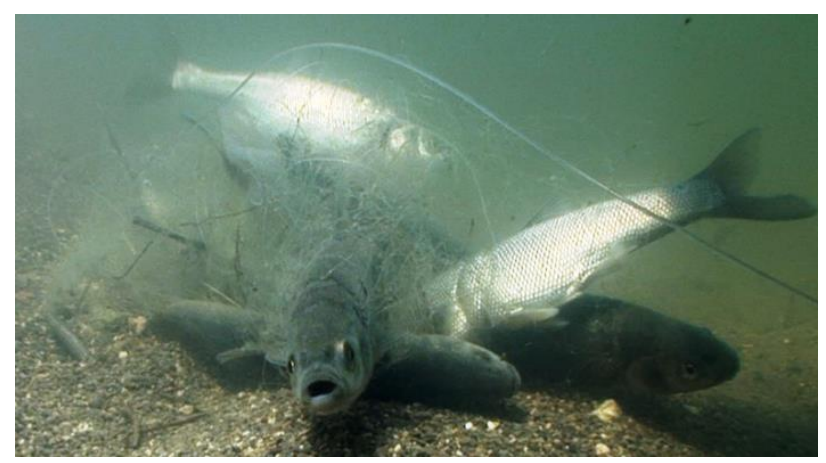

Figure 3: Fish caught in a broken monofilament gill net

About $60 \mathrm{~km}$ of the Çatak Stream has lost its original structure completely due to stream improvements. Furthermore, sand and gravel excavation operations conducted at three different locations disrupted the stream's physical habitat and resulted in turbid water flow. The deterioration of the physical habitat is particularly extreme in the area between Çatak district and Bilgi village. Due to the stream reclamation work conducted in this approximately $30 \mathrm{~km}$ long area, the water level of the stream bed increased and the stream completely lost its natural structure. In certain areas, the curved structure of the stream was removed and the stream was transferred into a narrow channel and the natural structure of the stream bed was completely destroyed (Fig. 4).

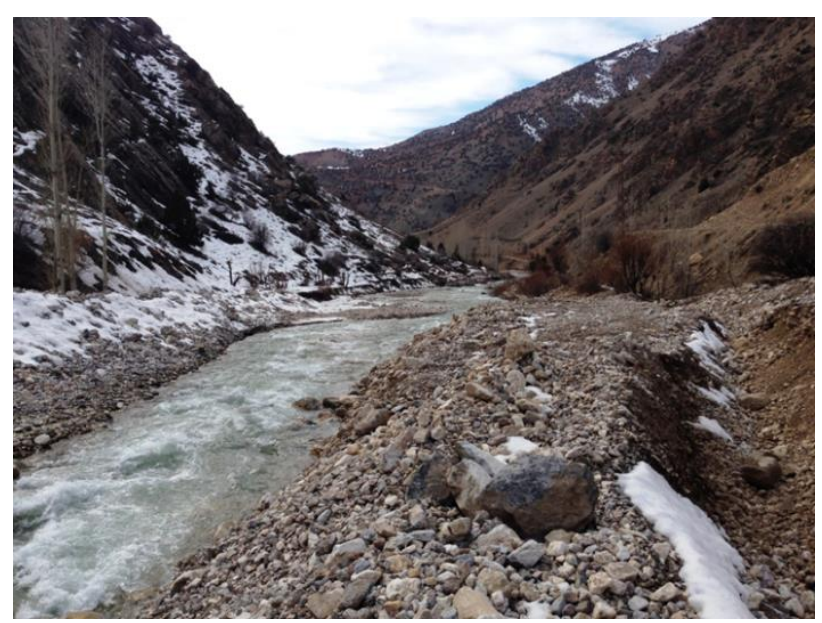

Figure 4: Deterioration in the stream bed

Clear streams with abundant oxygen and pebble beds at high altitudes are suitable habitats for Tigris trout. However, due to the destruction of the physical habitat in the Çatak Stream, the water quality deteriorated and the stream now has a turbid flow during half of the year. The curved structure of the stream and the stream bed were covered by large rocks. This structure in streams slows the water flow and provides adequate feeding and breeding areas for tigris trout. The so-called improvement work conducted on the stream removed the curved structure and rocks on the stream bed, hence destroying Tigris trout habitats.

\subsection{Fish farms on the stream}

The rivers and streams inhabited by Salmonids have cold, clean, and oxygen-rich waters and are also suitable for rainbow trout aquaculture. Thus, rainbow trout farms are continuously constructed on the rivers or on the branches of the stream where the native trout inhabit (Fig. 5). The fish medicines used in these farms and the escaping rainbow trout from the farms have negative effects on the river ecosystem and natural fish populations around these farms. There are three trout farms on Çatak Stream and one on Taşlıyazı stream drainage of Çatak. It was reported by Akkuş (2016) that fry and adult rainbow trout escape from these farms might have negative effects on Tigris trout stocks living in the Çatak Stream.

Considering the ever-increasing demand in the region, it is inevitable that trout farming on the Çatak Stream would increase in the following years.

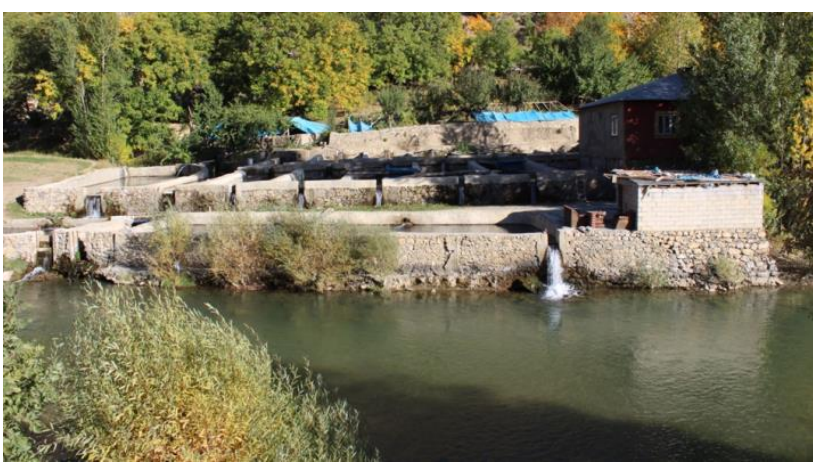

Figure 5: A rainbow trout farm on Çatak Stream.

\subsection{Deterioration of Water Quality}

Trout prefers clean, oxygen-rich waters. Thus, the deterioration of water quality negatively affects the trout in the stream. The presence of industrial facilities, residential buildings, and use of agricultural fertilizers on riverbanks are among the main causes of pollution in rivers (Toroglu et al. 2006, Koca 2015). The absence of any industrial establishment around the Çatak Stream ensured that the stream remained relatively clean with regard to industrial wastewater. The valley is composed of steep slopes and there is no suitable land for cultivation. Thus, there is no pollution due to agricultural fertilizers in the Çatak Stream. With 21,780 population, the largest riverside settlement is Çatak district and the other settlements include small villages with no more than 1000 inhabitants (Fig. 1). The garbage, ashes, and wastewater of these settlements are discharged directly to the stream untreated. Especially downstream from Çatak district, pollution due to solid waste is significant. Another problem in water quality is turbidity. Due to overgrazing in the stream, vegetation cover has been destroyed considerably. The destruction of vegetation increased soil erosion in the Çatak Stream (Restrepo and Syvitski 2006, Gray et al. 2011). It was observed that 
turbidity increased with the precipitation between October and March during Tigris trout's breeding season. It is obvious that the increased turbidity during the trout breeding season would have a negative effect on the offspring that would come out of the eggs and on the larvae stage. Another adverse effect of turbidity on the Tigris trout stock is that certain sediment deposits accumulate in the river upstream that is considered as the trout zone. The sediment accumulation on the riverbed destroys the fish breeding and feeding sites (Barbour 999). Sediment accumulation due to turbidity in the upstream endangers the stock by destroying the suitable breeding and feeding habitats for Tigris trout.

\section{Discussion}

Trouts are overfished all-around Turkey due to their delicious taste (Alp and Kara 2004, Korkmaz 2005). In addition to overfishing, inability to enforce current legislation led to a gradual decline in trout stocks in inland waters. According to the communique issued to regulate amateur fishing in the Çatak Stream (No. 4/22016/26) (Annex 5), year-round fishing is prohibited in the section between Taşliyazı and Elmacı streams that drain to Çatak Stream at Çatak district. In other sections, fishing is prohibited between 1 October and 28 February. In the Çatak Stream, Tigris trout hunting is widely conducted with Paraşüt and other fishing gears. According to article 9 of the communique issued to regulate amateur fishing no. $4 / 2$, utilization and sale of Paraşüt is prohibited in Turkish inland waters. Enforcement of the legislation effectively in the field by competent authorities could prevent the use of prohibited fishing methods and remove the pressure of overfishing on the Tigris trout stock. Another issue that threatens the Tigris trout stock is the destruction of the physical habitat in the stream. Sand and gravel excavation operations are conducted at three different locations on the stream. These operations disrupt the stream bed and increase water turbidity. Illegal sand and gravel excavation operations should be prevented. Rainbow trout that escape to the river from aquaculture farms are potentially objectionable fish species ecologically in inland waters according to the amateur fishing communique no. $4 / 2$. In the communique, it was stated that the rainbow trout eats the indigenous fish eggs and destroys their offspring. It was also stated that rainbow trout, which is more resistant to diseases, have the risk of infecting Tigris trout with diseases when they flee to the natural environment. Thus, rainbow trout fleeing from the farms built on the Çatak Stream should be avoided. There are no recreation pools for the last exit waters of the fish farms built on the Çatak Stream. Effluents are directly discharged to the stream and several rainbow trout to flee in these waters. The construction of stilling pools on these farms and barring the effluents with screens would reduce the fleeing fish. The deterioration of water quality in rivers has negative effects on fish stocks (Pond et al. 2006). The waste of the Çatak district and other villages around the Çatak Stream are discharged directly to the stream without any treatment. Especially in Çatak district, sewage causes a visible pollution in the stream due to the direct discharge of the waste. Sewage waste in the Çatak district center must be treated before its discharge to the stream. Furthermore, the collection of the waste from the villages in the district landfill would help reduce the pollution in the stream.

Acknowledgments: This study supported by Scientific Research Projects Department of Van Yüzüncü Yil University. Project ID: 2015-FBE-D168.

\section{References}

Akkuş, M. 2016: Balıkçılık yönetimi için Çatak Çayı'nda fiziksel-kimyasal ve biyolojik parametreleri esas alan yeni bir indeks geliştirilmesi üzerine çalışmalar. Yüzüncü Yıl Üniversitesi, Fen Bilimleri Enstitüsü, Doktora Tezi.

Alp, A., Kara, C. 2004: Ceyhan, Seyhan ve Fırat Havzalarındaki doğal alabalıklarda (Salmo trutta macrostigma Dumeril, 1858 ve Salmo platycephalus Behnke, 1968) boy, ağırlık ve kondüsyon faktörleri. Ege Üniversitesi Su Ürünleri Dergisi, 21 (1-2): 9-15.

Altındağ, A., Ahıska, S. 2006: Kesik köprü Baraj Gölü (Ankara) balıkçılık sorunları. I. Balıklandirma ve Rezervuar Yönetimi Sempozyumu, 07-09 Şubat, Antalya.

Aras, N. M. Kocaman, E. M. Aras, M. S. 2000: Genel su ürünleri ve kültü̈ balıkçılığının temel esasları. Atatürk Üniversitesi Ziraat Fak. Ders Yayınları, No: 216, Erzurum.

Aras, S., Çetinkaya, O., Karatas, M. 1997: Anadolu Alabalığı (Salmo truttı macrostigma, Dum., 1858)' nin Türkiye'deki bugünkü durumu. Akdeniz Balıkçlık Kongresi, 9-11 Nisan. İzmir. 605-613.

Ateşşahin, T., Ergün, A., Özmen, M.M. 2014: Elazı ğ ilindeki amatör balıkçıların sosyo demografik özellikleri üzerine bir ön araştırma. Yunus Araştırma Bülteni, 1: 41-51.

Barbour, M.T., Stribling, J.B. 1999: Use of habitat assessment in evaluating the biological integrity of stream communities. In Biological Criteria: Research and Regulation. Environmental Protection Agency, EPA440/5-91-005.

Cetinkaya, O. 1996: Investigations of some biological proporties of Tigris trouts (Salmo trutta macrostigma Dum., 1858) living in the Catak Stream (Tigris River, Turkey), (in Turkish). İstanbul Üniversitesi Su Ürünleri Dergisi, 9-13 (1-10): 111-122.

Dönel, K.E., Yılmaz, E. 2016: The Fish fauna of Gaga Lake (Ordu-Turkey) and identification of four species by morphometric characteristics. Journal of Maritime and Marine Sciences, 2 (2): 8-19.

Gray, M. S., Sabbah, S., Hawryshyn, C. W. 2011: Experimentally increased turbidity causes behavioral shifts in Lake Malawi cichlids. Ecology of Freshwater Fish, 20: 529-536.

Kara, C., Alp, A., Emre, Y. 2007: Salmo trutta macrostigma Dumeril, 1858'nın Ceyhan Nehir sistemi'nde dağılımı ve bazı morfometrik özellikleri. Türk Sucul Yaşam Dergisi, 5 (8): 77-86.

Kaya, C., Turan, D., Ünlü, E. 2016: The Latest Status and Distribution of Fishes in Upper Tigris River and Two New Records for Turkish Freshwaters. Turkish Journal of Fisheries and Aquatic Sciences, 16: 545-562.

Koca, C. 2015: Yalova'daki su potansiyelinin değerlendirilmesine bir öneri: Bütüncül Su Yönetimi. 3. Uluslararası Bölgesel Kalkınma Konferans1, 15-16 Ekim, Bingöl.

Korkmaz, A. Ş. 2005: Kadıncık Deresi'ndeki (Çamlıyayla-Mersin) balık yoğunluğu ve biyoması. Tarım Bilimleri Dergisi, 11 (1): 91-97.

Kurtoğlu, İ. Z., Çelikkale, M. S., Okumuş, İ. O., Aksungur, M., Çakmak, E. Firidin, Ş., Aksungur, N., Çavdar., Y., Zengin, B. 2009: Karadeniz Alabalığında (Salmo Trutta Labrax) smoltifikasyonun belirlenmesi için kan parametrelerinin analizi. Doğal Alabalık Çalıştayı: Sürdürülebilir, Koruma ve Balıklandırma, 22-23 Ekim, Trabzon.

Pont, D., Hugueny, B., Beier, U., Goffaux, D., Melcher, A., Noble, R., Rogers, C., Roset, N., Schmutz, S. 2006: Assessing river biotic condition at a continental scale: a European approach usingfunctional metrics and fish assemblages. Journal Applied Ecology, 43: 70-80.

Restrepo, J. D., Syvitski, J. P. M. 2006: Assessing the effect of natural controls and land use change on sediment yield in a major Andean river: The Magdalena drainage basin, Colombia. Journal of the Human Environment, 35(2):65-74.

Saraçoğlu, H. 1990: Bitki örtüsü akarsular ve göller. İstanbul: Milli Eğitim Basımevi 
Akkuş et al. (2017) Comm. J. Biol. 1 (1) : 16-20.

Toroğlu, E., Toroğlu, S., Alaeddinoğlu, F. 2006: Aksu Çayı'nda (Kahraman

Maraş) akarsu kirliliği. Coğrafi Bilimler Dergisi, 4(1): 93-103.

Turan, D., Kottelat, M., Bektaş, Y. 2011: Salmo tigridis, a new species of trout from the Tigris River, Turkey (Teleostei: Salmonidae). Zootaxa, 2993: 23-33. 